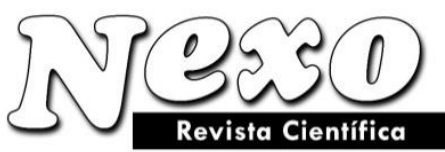

Vol. 34, No. 01, pp. 24-42/Marzo 2021

\title{
Environmentally friendly technologies of oil products extraction in oil- containing wastes purification
}

\section{Tecnologías de extracción de productos petrolíferos respetuosas con el medio ambiente para purificar residuos con hidrocarburos}

\author{
Maral Abdibattayeva ${ }^{1 *}$, Kylyshbay Bissenov ${ }^{2}$, Zheniskul Zhubandykova $^{3}$, Raigul Orynbassar ${ }^{4}$, \\ Lyazzat Tastanova $^{4}$ \\ ${ }^{1}$ Al-Farabi Kazakh National University, Republic of Kazakhstan \\ ${ }^{2}$ Korkyt Ata Kyzylorda State University, Republic of Kazakhstan \\ ${ }^{3}$.K. Zhubanov Aktobe Regional State University, Republic of Kazakhstan \\ 4.Aktobe Regional State University, Republic of Kazakhstan \\ *maral7676@mail.ru
}

(recibido/received: 02-November-2020; aceptado/accepted: 17-December-2020)

\begin{abstract}
Significant oil losses in oil-containing wastes and their adverse impact on the region's environmental setting bring about the need to develop an oil-containing wastes treatment technology. To tackle this issue, the authors have set an aim of designing a helio device and creating an oil-containing wastes treatment method based on it to extract oil products. Considering a wide spread in the composition and properties of potential oil sludge raw materials and their tendency for either formation of stable emulsions or phase separation, we have conducted in-depth modern physical and chemical studies and defined the need to develop a commercial oil-containing wastes purification method. We have designed the device, in which oil product hydrocarbons undergo thermal treatment using solar energy without prejudice to their chemical structure. Following oil-containing wastes purification using solar energy, the particulate load in soil does not exceed $6.65-6.79 \%$ and the absolute molecular weight of hydrocarbons approaches that of bitumen. The oil-containing wastes purification method developed solves an important environmental issue of oilcontaining wastes recycling, promotes recovery and prevents degradation of natural complexes, and reduces soil and water pollution.
\end{abstract}

Keywords: Helio device; Oil-containing wastes; Oil-containing wastes purification; Thermal treatment; Treated soil.

\section{RESUMEN}

Pérdidas sustanciales de petroleo en residuos con hidrocarburos y su efecto negativo en el medioambiente regional hace necesario desarrollar una tecnología de purificar residuos con hidrocarburos. La tarea aquí determinada es deseñar un dispositivo solar y desarrollar un método de tratar residuos con hidrocarburos en este dispositivo con la obtención de productos petrolíferos. La gran variabilidad en las propiedades y composición de la materia prima de lodo oleoso y su tendencia a formar emulsiones estables o a la separación en fases hizo necesario llevar a cabo un estudio físico y químico detallado y predeterminó la demanda de desarrollar un modo industrial de purificar residuos con hidrocarburos. El dispositivo 
diseñado usa la energía solar para el tratamiento térmico de los hidrocarburos de productos petroliferos sin ningun daño a su estructura química. Al purificar residuos con hidrocarburos con la ayuda de energía solar, el contenido de residuos sólidos en el subsuelo no sobrepasa 6.65-6.79 \% y el peso absoluto molecular de hidrocarburos se hace próxima al peso absoluto molecular de betún. El método de tratamiento desarrollado resuelve el problema medioambiental importante de eliminar residuos con hidrocarburos, estimula la restoración de conjuntos naturales, previene su degradación y reduce la contaminación de la capa de suelo y cuencas de agua.

Palabras claves: Dispositivo solar; Residuos con hidrocarburos; Purificación de residuos con hidrocarburos; Tratamiento térmico; Subsuelo purificado.

\section{INTRODUCTION}

Although Kazakhstan is located at the latitude between 42 and 55 degrees northward, the solar radiation potential in the republic is quite high $-1,300-1,800 \mathrm{kWh} / \mathrm{m}^{2}$ a year. Because of inland climate, there are 2,200-3,000 solar hours a year. This high potential of solar energy enables its economic use in Kazakhstan. The annual solar energy potential in oil-producing regions is $0.652 * 10^{15} \mathrm{~J}$. Thus, wide use of solar energy may be of high economic value here. Use of the solar energy potential in oil field regions for the processing of accumulated and current oil-containing wastes during oil production defines the technical feasibility of this work. Besides, solar technology development is an innovative focus area for Kazakhstan that does not have enough utility capacity to meet the entire power demand.

Each year, some $3 \mathrm{mln}$ tons of oil-containing wastes is generated on a global scale with over $100^{\text {th }}$ tons in Kazakhstan. Significant oil losses in oil sludge and other types of oil-containing wastes and their adverse impact on the region's environmental setting brings about the need to develop the oil-containing wastes treatment technology.

The issue of oil-containing wastes purification is a burning one everywhere. However, as of now, there is still no efficient industrial scheme of its processing, although attempts to design and improve treatment and recovery equipment have been made by nearly all leading chemical plant manufacturers. World's first separation plants for oil sludge treatment were designed and installed in Russia. These separators were intended for oil sludge purification, but they turned out to be inefficient as after each work shift, work faces had to be disassembled and cleaned. Project developers ignored one major thing: raw materials were fed to separators untreated, while it is feasible to use separators only at the last stage of oil sludge treatment. This is why these separation methods did not find further application. Other plants used oil sludge, sludge collector sediment and floating foam incinerators for 10-15 years. This oil sludge processing also proved to be inefficient as, in addition to oil losses, extra fuel was consumed to evaporate water and maintain operating temperature in the oven. Other drawbacks of the plant include impossibility to remove sulphur and nitrogen oxides from fuel gases generated during sludge burning and the need for additional preparation of raw materials for burning (Guangji \& Jianbing, 2013; V. Smykov, Yu. Smykov \& Torikov, 2005).

An improved version of the oil sludge purification plant was designed by Swiss company Alfa Laval. The purification goes on as follows: oil sludge is pumped into a tank and is left for a few days to settle. Water that appears on the surface is drained to purification plants and oil phase is fed to the Alfa Laval plant. First, oil phase gets in a hydroclone followed by a two-phase centrifuge where heavy solids are removed. Next, oil is purified (to remove water) in a three-phase ratio separator. Operation yielded an unpromising conclusion: this plant is only suitable for fresh newly formed oil sludge and can hardly be used to treat sludge collector sediment. Besides, water generated during purification is polluted with stable crude oil and solids (soil) that are periodically removed from separators cannot be treated. Another deficiency is 
that no chemical reagents (demulsificators) are used to break down stable crude oil and improve purification efficiency (Obrevka, Frolova \& Darisheva, 2002).

An oil sludge purification plant by German manufacturer KHD was offered to several oil producers. At the initial purification stage, oil sludge is pumped into a container. From this container, oil phase is pumped into a three-phase centrifuge where oil sludge is separated into oil, water, and solids under centrifugal force. To improve purification efficiency, oil sludge is treated with a chemical reagent before loading it in the centrifuge. This plant has the following drawbacks: to reach oil content in the oil sludge fed to the plant of at least $70 \%$, high separation value must be attained in the tank. Otherwise, refined oil will have high water content. Unlike a three-phase ratio separator, purification in a centrifuge is not automatic. KHD can also treat freshly formed oil sludge only and is not suitable for sludge collectors sediments. Oil sludge processing using centrifuges requires much energy to enable oil separation from other components. Belt pressure filters are used in addition to centrifuges. However, these machines only separate soil and water. Resulting soil still contains from 20 to $30 \%$ of hydrocarbons (Guangji \& Jianbing, 2013; Singh et al., 2016).

The oil-containing wastes purification method developed by American company Bogart Environmental Services has been successfully used at Kuwait fields for several years now. This method enables removal of oil spills from sandy soil after accidents. To this end, contaminated soil is removed into high (up to 10 meters) piles. Oil is pressed out under the soil weight. Next, oil is fed to a centrifuge for treatment. Soil is diluted with water to a moisture content of $95 \%$ and is delivered to containers where hydrocarbons undergo biological destruction. The use of Bogart equipment and methods for light-textured soil treatment brings about certain difficulties. Firstly, these soils are almost impossible to arrange in piles. This means that soils undergo biological treatment virtually without free oil separation, while microbiological methods are only efficient with hydrocarbons content of no more than 15\%. It should also be noted that soil must be diluted with clean water to ensure effective action of microbiological strains. Deficiencies of the method also include demand for much clean water and significant extension of the treatment time.

It should be remembered that microorganisms contain toxic elements and compounds. The volume of microorganisms removed with treated soil is directly proportional to the nutrition introduced in soil (hydrocarbons). The more hydrocarbons are delivered for biodestruction, the more excessive biomass will result from treatment. Treatment of soils with a high content of hydrocarbons may increase the number of harmful elements in cells, which may result in biological pollution of the environment.

To keep biodestruction going during biological treatment, much biomass has to be renewed. To this end, landfills are fitted with reactors to produce his biomass. This comes from additional costs on biomass growth media and additives. Enzymes are used to reduce the volume of biomass, which makes the method quite costly (Singh, et al., 2016; Estrada-Arriaga, Zepeda-Aviles \& Garcia-Sanchez, 2016; Scriru, 2018).

To tackle this issue, the authors have designed a helio device and created an oil-containing wastes treatment method based on it to obtain oil products. The method has passed laboratory and extended laboratory tests at al Farabi's Kazakh National University and Almaty University of Technology. This technology has been tried at oil-polluted soils and oil sludge of Kazakhstan oil producers. Research and development have been conducted to design the helio device and test it with various oil-containing wastes types. Positive results obtained confirm cost-effectiveness of oil-containing wastes processing that implies mitigation of damage to environment and economy from waste disposal and profit from obtaining additional oil volumes.

Scientific novelty of the work lies in the design of the helio device and method of oil products extraction during oil-containing wastes purification that enable maximum recovery of hydrocarbons from oil waste without prejudice to their chemical structure. 
Almost no oil producer in Kazakhstan has an industrial oil-containing wastes purification scheme. Each year, only one oil-producing region generates some $50-100^{\text {th }}$ tons of oil-containing wastes that implies significant losses of oil produced. Besides, accumulation of this waste is a huge environmental threat to neighboring regions. This work envisages oil-containing wastes processing using the helio device to obtain oil products and treated soils.

Organic fracture of oil waste is a quite complex mixture of hydrocarbons of varying structural-group composition and their hetero-derivatives with a broad range of physicochemical properties (Stilianos \& Fitzgerald, 2000). Most researchers use thermal methods to extract hydrocarbons.

Despite available methods (Kurbskiy, 1987; Pak, 1997; Swanberg, 1993, Abdrakhmanov, Zakirov \& Andreyev, 1997; Taciuk, 1993), the effect of temperature on heat processing has not been properly studied yet. Despite high extraction of organic waste fracture, proposed heat methods have the following drawbacks: high cost of plants, complexity of process flow schemes and high smoke release due to burning-out of oil that has been recovered with difficulties from the subsoil in the burning area.

The developed efficient method of oil-polluted soil and oil sludge purification using solar energy prevents heat loss during heating over a light day and ensures required environmental temperature conditions and high recovery of productive oil.

\section{MATERIALS AND METHODS}

The following has been used as the experimental research methodology:

- analysis of theoretical assumptions;

- review of the main characteristics of the object under study subject to various restrictions imposed by immediate experimental tasks;

- review of the application and operational characteristics of the oil-containing wastes treatment method developed.

The methodology is elaborated with a primary focus on the conditions that ensure consistent results. Data obtained is used to select prototype models, equipment, establish simulation parameters, calculate a number of individual experiment repetitions.

Both generally recognized traditional and non-traditional analysis methods were used during research. Various modern and classical physicochemical analysis methods were used to determine morphology, structure and chemical composition of samples. Empirical data obtained was used with the application of induction and deduction methods to establish theoretical knowledge that was practically grounded, which will remove its speculative nature and turn it into direct knowledge.

Pilot studies were conducted directly on the object of study and (additionally) on artificial solutions to eliminate side effects on studied phenomena. Physical and chemical parameters of oil-containing wastes were assessed using standard methods. The source information derived from tests was analyzed using computer programs based on elements of the theory of chances and mathematical statistics.

Oil-polluted soil and oil sludge of Atyrau region where large oil and gas fields of Kazakhstan are concentrated were used for research. Their composition is provided in table 1. 
Table 1. Composition of oil waste

\begin{tabular}{llll}
\hline Oil waste & \multicolumn{2}{l}{ Composition, w \% } & \\
\cline { 2 - 4 } & Organic fraction & Solids & water \\
\hline Oil sludge & 76.8 & 8.0 & 15.2 \\
Oil-polluted soil & 11.6 & 85.4 & 3.0 \\
\hline
\end{tabular}

Physicochemical properties of polluting oil products are also important. Cluster analysis of oil sludge under study was conducted by gas chromatography with mass-spectrometer detection (Robinson, Cundiff R\& Markunas, 1961; Stilianos \& Andrew, 1997).

Oil waste was treated to separate oil components from the bulk of the waste. The oil fraction of the waste was analyzed to select conditions for its extraction.

Fractional makeup of an oil sample provided was determined by simulated distillation using a gas chromatograph with mass spectrometric detector [ASTMD2887] with the modifications set out in (Robinson, Cundiff R\& Markunas, 1961).

The oil sample for analysis was dissolved in chloroform in 3:1 and $1.0 \mu \mathrm{l}$ of the resulting solution was introduced using Combi-PAL autosampler (CTCAnalyticsAG, Switzerland) in 7890A gas chromatograph loader (Agilent, US) heated to $300^{\circ} \mathrm{C}$ with a split ratio of 30:1.

Separation was made by DB-35MS column (Agilent, US) $30 \mathrm{~m}$ long with an inner diameter of $0.25 \mathrm{~mm}$ and the film thickness of $0.25 \mu \mathrm{m}$. Chromatography temperature was set from $40^{\circ} \mathrm{C}(5 \mathrm{~min}$ exposure) with a heating rate of $10^{\circ} \mathrm{C} / \mathrm{min}$ to $320^{\circ} \mathrm{C}(15 \mathrm{~min}$ exposure).Detection was made by $5973 \mathrm{~N}$ mass-spectrometer (Agilent, US) with total ion current recording in the mass number range of 10-550. The mass-spectrometer interface temperature was $300^{\circ} \mathrm{C}$.Chloroform was used as a reference sample.

For the purposes of benchmarking effects of various sources of energy on thermal treatment of oilcontaining wastes, experimental works were conducted in two ways:1) using solar energy; 2) using electric energy.The first method implies the use of solar energy to heat oil-containing wastes. The second method uses electric energy to heat oil-containing wastes. After the heating using different methods was performed, conditions were recorded with meters. Complex analysis using a well-known physicochemical study method was made after thermal treatment.

Studies using a differential thermal analysis of oil-containing wastes were also conducted before and after thermal treatment using different sources of energy. The differential thermal analysis was conducted using Derivatograph $\mathrm{Q}-1500 \mathrm{D}$ with a heating rate of $10^{\circ} \mathrm{C}$ per minute to $1,000^{\circ} \mathrm{C}$.

\section{RESULTS AND DISCUSSION}

Experimental studies were conducted in Almaty. Solar radiation in the region is $1,343 \cdot 10^{15} \mathrm{~J}$ a year. Table 2 below provides estimates of total solar energy insolation by months in Almaty.

Table 2. Total solar energy insolation by months in Almaty.

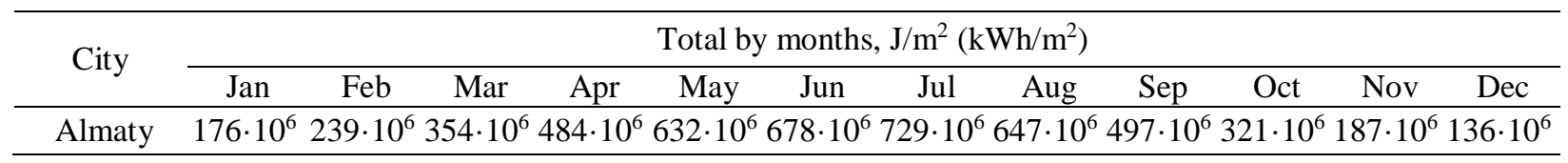

Wide spread in the composition and properties of potential oil sludge raw materials and their tendency for either formation of stable emulsions or phase separation requires a detailed study and defines the need to 
develop an innovative method based on non-conventional engineering solutions. We have offered a universal commercial oil-containing wastes purification method.

Hydrocarbon waste fraction analysis results are shown in figures 1-3 and table 3. For higher analysis precision, blank sample chromatogram was deducted from the chromatogram obtained and data was processed. The chromatogram obtained after deduction is shown in figure 1.

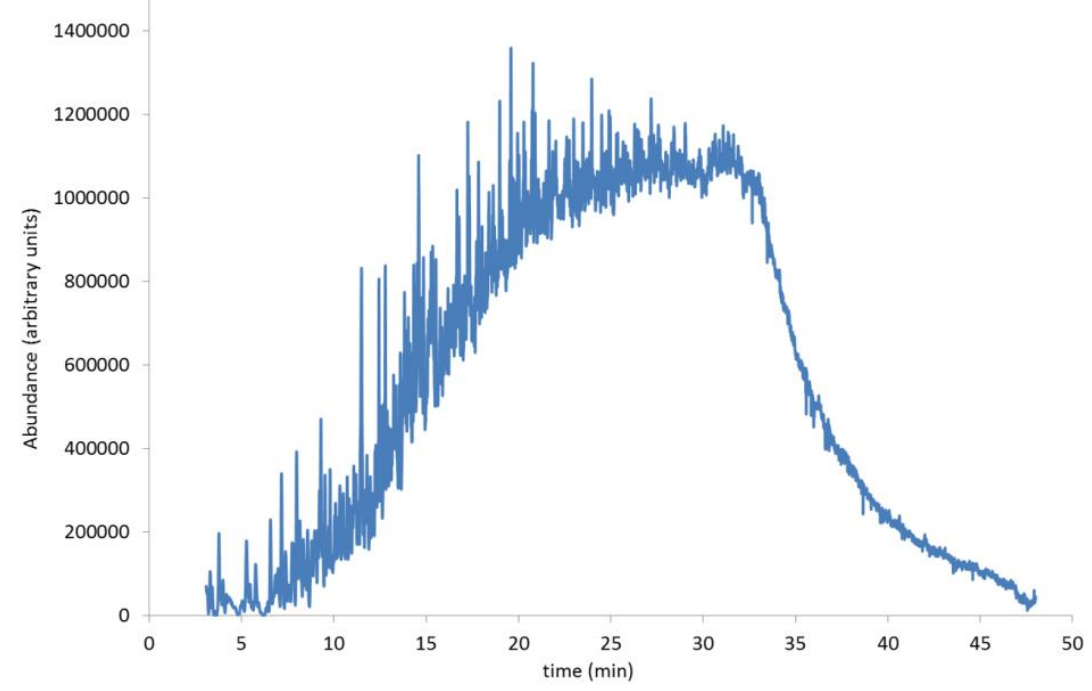

Figure 1. Chromatogram obtained after deduction of blank sample chromatogram from oil chromatogram

The oil distillation curve obtained is shown in figure 2. According to the method, mass fraction of distilled oil to $530-550^{\circ} \mathrm{C}$ is accepted as $100 \%$.

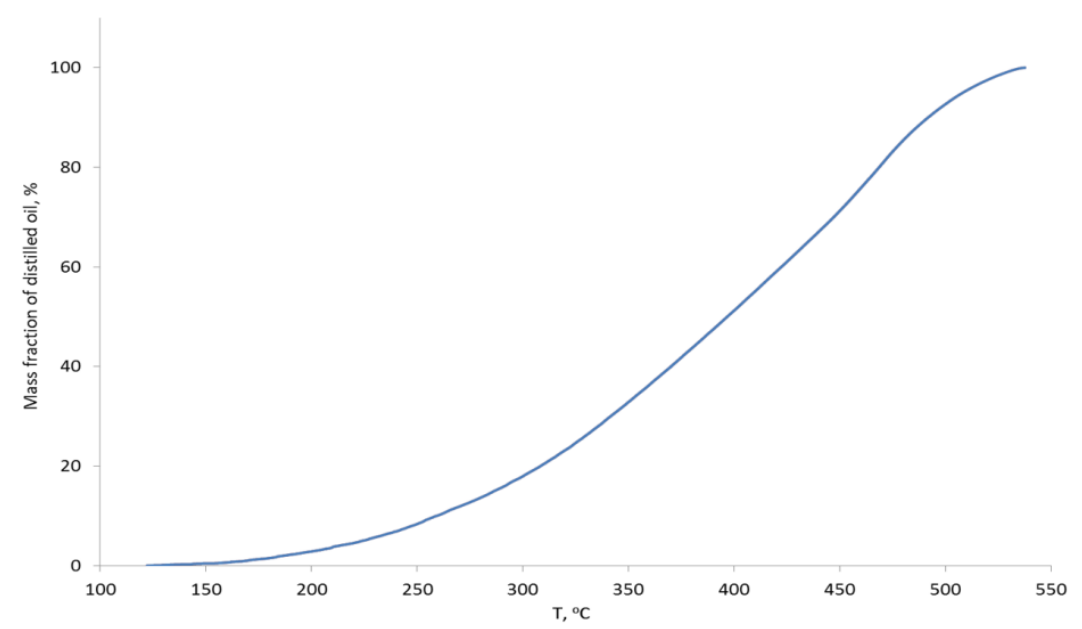

Figure 2. Oil sample distillation curve

Typical ion signals in the mass spectra recorded in each chromatogram point were used to identify individual compound classes (table 3). 
Table 3. Results of component analysis of volatile fraction of oil sample provided

\begin{tabular}{lc}
\hline Compound class & $\mathrm{W} \%$ \\
Paraffins & 15.32 \\
Uncondensed naphthenes & 22.13 \\
condensed naphthenes with 2 rings & 19.45 \\
condensed naphthenes + all naphthenes with 3 rings & 14.11 \\
Benzenes & 6.63 \\
Naphthene benzenes & 3.09 \\
Dinaphthene benzenes & 3.26 \\
Naphthalenes & 3.91 \\
Acenaphthenes & 3.91 \\
Fluorenes & 4.88 \\
Phenanthrenes & 3.31 \\
\hline
\end{tabular}

A distribution curve of saturated and aromatic hydrocarbons in the oil sample under study versus their boiling point (figure 3 ) was built using capabilities of the method in use.

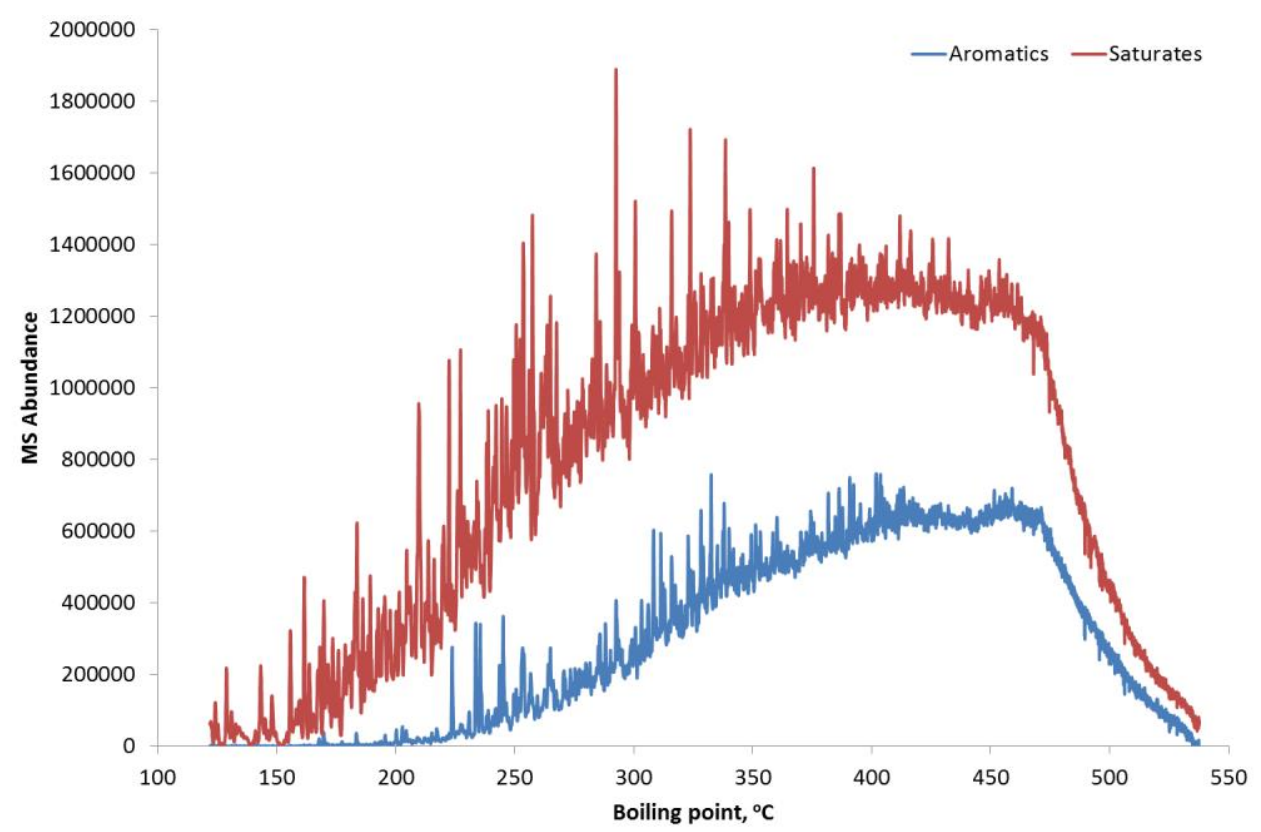

Figure 3: Distribution curve of saturated and aromatic hydrocarbons in the oil sample under study versus their boiling point

The studied oil sludge sample with a density of $942 \mathrm{~kg} / \mathrm{m}^{3}$ features typical predominant content of paraffins. Gasoline cut content is low - at a temperature of up to $200^{\circ} \mathrm{C}$, some $2 \%$ of the sample burns out. Diesel oil cut up to $350^{\circ} \mathrm{C}$ is $23 \%$ on the average and gasoil cut amounts to $16 \%$.It follows from the figures that the product of oil-containing wastes purification is valuable hydrocarbon material that may be processed or recycled.

The helio device, in which oil product hydrocarbons undergo thermal treatment using solar energy, has been designed to extract oil products. 
Helio device is a plant that transforms solar energy into heat energy. The optimal design of the plant has to ensure maximum use of solar energy. The optimal design of the device has to be created with regard to natural and climatic peculiarities of the region that are shown in figures 4-8.

Review of the current state of use of the helio device has revealed efficiency of application of solar energy cylindrical parabolic concentrators (CPC) for various industries. Tracking and fixed parabolic concentrators are most commonly used in plants that transform solar energy into heat and electric energy. Unlike point focus concentrators, they are easier to manufacture and more convenient for modular scaleup. Solar radiation estimates defined usability of the cylindrical parabolic concentrator in Atyrau region. We have elaborated helio device design specifications to enable processing of $5 \mathrm{~kg} /$ hour of oil waste in semi-continuous mode during daylight hours in spring, summer, and fall. Efficient operation of the entire system is guaranteed by the efficiency of all its functional parts. CPC parameters such as geometry, aperture angle, focal spot dimension, surface reflection power and accuracy of manufacturing must ensure the required level of solar energy concentration in the reflector's line focus.

The solar azimuth and elevation tracking system are based on the design constants that match the geography of concentrator installation and ensure the required rate of Polar axis rotation and height variation during the day depending on the season.

\section{Sun tilt $\delta=23,5 \cdot \sin [360 \cdot(284+n) / 365]$, deg.}

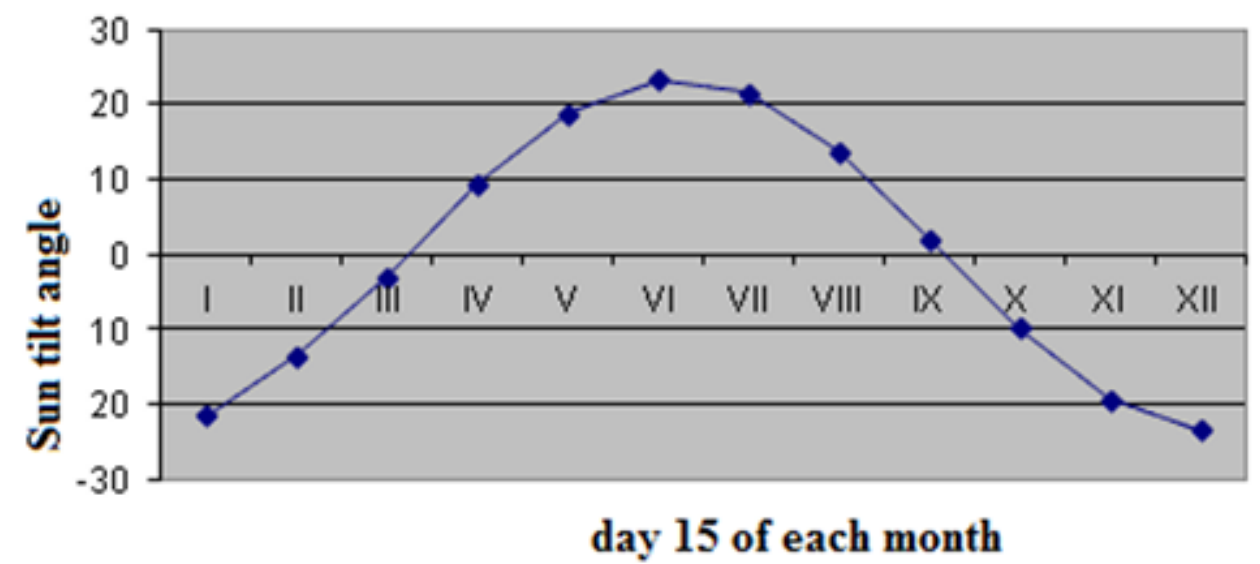

Figure 4: Sun tilt angle

$h=f(t)$

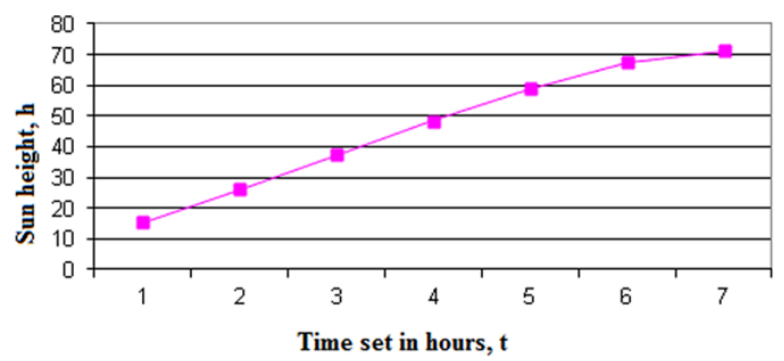

Figure 5. Sun height

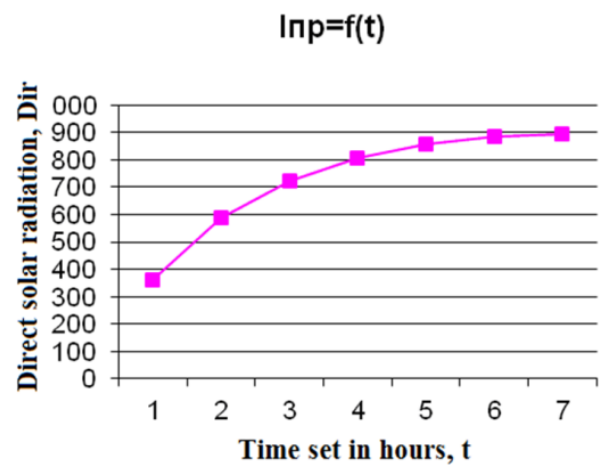

Figure 6. Direct solar radiation 
$\mathbf{D}(\mathbf{3 0})=\mathbf{f}(\mathbf{t})$

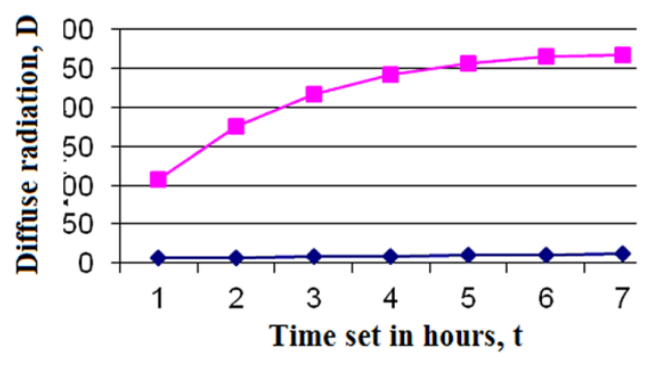

Figure 7. Diffuse solar radiation
$Q=\mathbf{f}(\mathbf{t})$

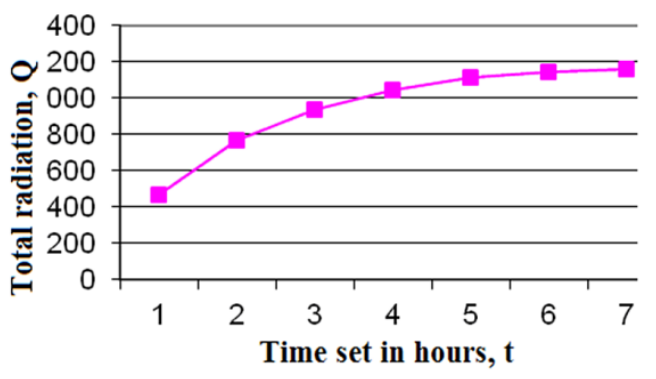

Figure 8. Total solar radiation

In order to track the system that would define source data to install the solar energy cylindrical parabolic concentrator in the required geographical location and, even more so, to ensure efficient solar azimuth and elevation tracking, it is required to determine the constant original values that will be used as the basis of calculations for actuators as part of the solar tracking system.

This installation has the following characteristics: power up to $250 \mathrm{~W} \pm 3 \%$; focus temperature up to $120^{\circ} \mathrm{C}$. Oil-containing wastes is treated in a cylinder-shaped reactor secured on top with a disk and rotor with blades. The integrated parabolic concentrator collects solar energy into a focus where the rotor with blades made of copper and with solar pointing is located. Heat that lacks on cloudy days and in the cold season is provided by a solar panel of $250 \mathrm{~W} \pm 3 \%$ and an electric heater assembled under the tank.

The device operates as follows: to promote conditions for oil displacement from soil, oil-polluted soil or oil sludge is mixed with water and, once soil is saturated with water, cavities are formed, via which oil fractions begin to escape during heating by solar energy. Another benefit of this helio device is its automated operation; the solar collector automatically moves along the solar path, which ensures maximum concentration of solar radiation. Figure 9 shows the principal scheme of the helio device fitted with concentrating elements.

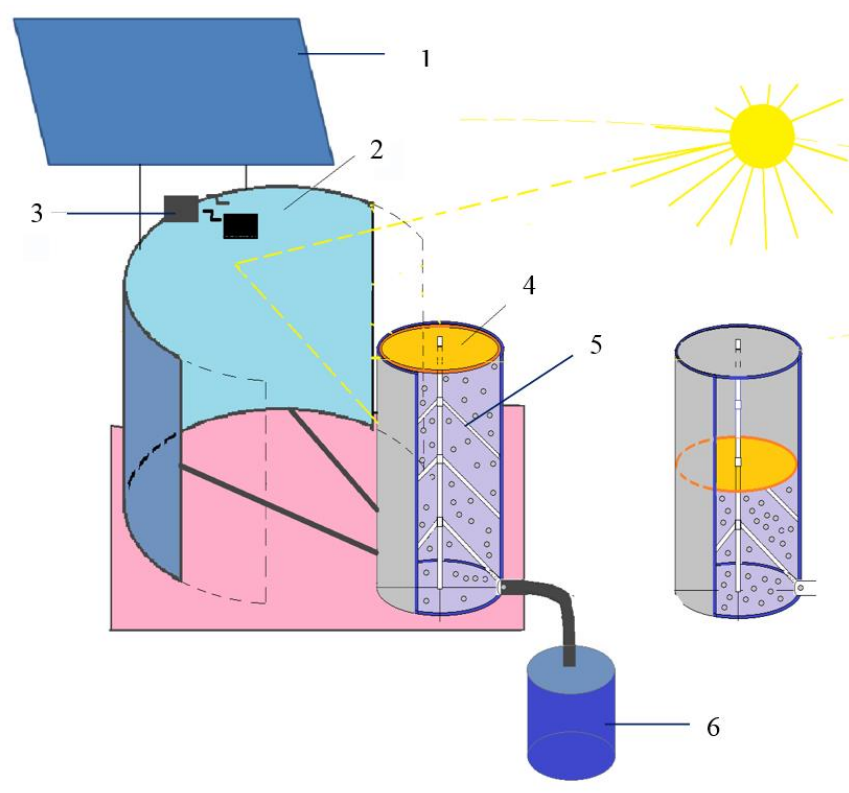

Figure 9. Device for oil and oil products extraction during oil-containing wastes purification.

1-solar panel; 2-cylindrical parabolic concentrator; 3-solar energy tracking system; 4-disk for oil displacement with pressing; 5-rotor with blades for heated waste mixing; 6-displaced oil discharge tank 
During the experiment with oil waste heating, the device temperature was $75-82^{\circ} \mathrm{C}$ with an ambient temperature of $33-35^{\circ} \mathrm{C}$; heating was conducted during daylight hours. Changes of oil-containing wastes temperature in the helio device fitted with concentrating elements are shown in figure 10.

To promote conditions for oil displacement from soil, oil-polluted soil or oil sludge is mixed with water. To this end, the device is filled with water and oil-polluted soil or oil sludge is introduced on top. The focus part of the body is fitted with a parabolic concentrator with the solar tracking system on a metal frame. This concentrator focuses direct and disperse solar radiations, collects solar energy and forwards it to the focus part of the tank. Any material with reflection power may be used as a solar energy concentrator.

The helio device is fitted with solar panels made of concentrating solar modules mounted on the mechanical system that provides heat lacking on cloudy days and in the cold season. The tank bottom is fitted with an electric heater activated by the additional energy accumulated by the solar panel.

On top of the tank, there is a rotor with blades mounted on the disk; these blades mix the mixture being heated and oil fraction starts to escape through the cavities formed with the help of blades during heating with solar energy. To separate escaping oil from soil, the disk presses the mixture and resulting productive oil is drained into an oil tank through the pipe connected to the body.

During oil-polluted soil heating, the device temperature was 85 degrees Centigrade with an ambient temperature of 28 degrees Centigrade. Heating lasted 4 hours and when additional energy accumulated by the solar panel was used, the heating time reduced by 2-2.5 times. Oil-polluted and treated soil and oil sludge are loaded and discharged manually or mechanically, although this process may be automated.

In order to establish thermal effect of different sources of energy (solar and electric) on hydrocarbon properties, characteristics of waste thermal extracted organic fraction were studied. The hydrocarbon phase resulting from heat processing with solar energy is very different in its physicochemical properties compared to the hydrocarbon phase extracted electrically (Abdibattayeva, 2015; Abdibattayeva, Akhmedzhanov \& Zhubandykova, 2007).

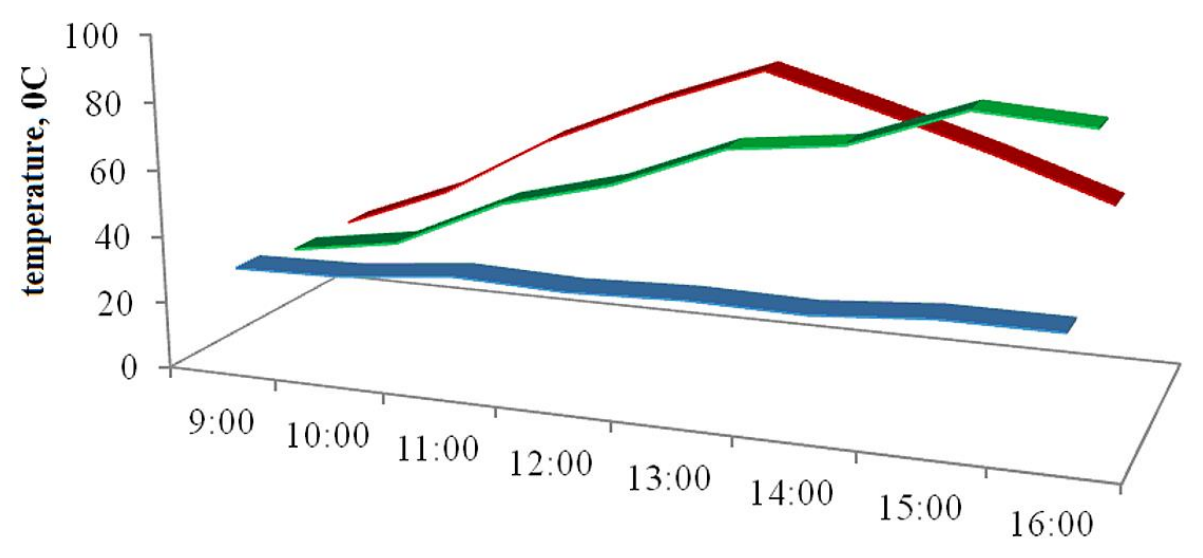

time, $\mathrm{h}$

$\square$ Row1 $\square$ Row2 $\square$ Row3

Figure 10. Oil-containing wastes temperature changes with various sources of energy.

Row 1-Ambient temperature; Row 2-Temperature of waste and water mixture during heat processing using solar energy; Row 3-Temperature of waste and water mixture during heat processing using electric energy 
The results of the analysis of oil extracted from oil-containing wastes are shown in table 4. It follows from table 4 that the content of chloride salts, water cut and sulfur content with electrical heating are much above allowances and result in changes in physicochemical properties of oil.

Table 4. Physicochemical properties of oil extracted from oil-containing wastes

\begin{tabular}{|c|c|c|c|c|c|c|}
\hline Properties and methods & $\begin{array}{l}\text { Density at } \\
20^{\circ} \mathrm{C} \text {, } \\
\mathrm{kg} / \mathrm{m}^{3}\end{array}$ & $\begin{array}{l}\text { Density of } \\
\text { oil } \\
\text { recovered, } \\
\mathrm{kg} / \mathrm{m}^{3}\end{array}$ & $\begin{array}{l}\text { Content of } \\
\text { chloride } \\
\text { salts, mg/l }\end{array}$ & $\begin{array}{l}\text { Water } \\
\text { cut, } \%\end{array}$ & $\begin{array}{l}\text { Content of } \\
\text { solids }\end{array}$ & $\begin{array}{l}\text { Sulfur } \\
\text { content }\end{array}$ \\
\hline Standard as per ND & 830.0 & 833.7 & 100 & 0.5 & 0.05 & 0.6 \\
\hline $\begin{array}{l}1^{\text {st }} \text { method (heating using } \\
\text { solar energy) }\end{array}$ & 948.0 & 942.7 & 127.480 & 18.0 & 0.0349 & 0.168 \\
\hline $\begin{array}{l}2^{\text {nd }} \text { method (heating using } \\
\text { electric energy) }\end{array}$ & 852.1 & 942.7 & 407.9 & 35.0 & 0.0394 & 0.265 \\
\hline
\end{tabular}

When solar energy is used, the conditions required to extract oil from soil are established. As it follows from the figures provided, the product of oil-containing wastes purification is valuable hydrocarbon material that may be processed or recycled (Abdibattayeva, 2013; Abdibattayeva, Bisenov \& Rysmagambetova, 2016; Abdibattayeva, Umbetbekov \& Kalimbetov, 2015; Abdibattayeva, Berdikulova \& Beketova, 2014).

Next, oil-containing wastes purification activation energy is calculated. In these cases, the following equation describes physical and chemical processes that occur during oil waste treatment using solar energy:

$$
\left[1-(1-\alpha)^{1 / 3}\right]^{2}=\mathrm{k} \tau
$$

Equation (1) describes the reactions that start over the entire surface of substance and continue throughout the volume at a constant linear time-dependent speed.

The results of experimental data processing using formal kinetic equations are given in tables5-6.

The activation energy value is calculated as follows [23-29]:

$$
\mathrm{E}=\frac{R \cdot \ln \left(K_{n+1} / K_{n}\right)}{1 / T_{n}-1 / T_{n+1}}
$$

where $\mathrm{R}$ is a gas constant equal to $8.31 \mathrm{~J} / \mathrm{Kmol} ; \mathrm{Kn}+1, \mathrm{Kn}$ is rate constant at the initial and final temperature, min-1; $\mathrm{Tn}+1$, Tn are initial and final temperatures, $\mathrm{K} . \mathrm{K}$ and $\mathrm{E}$ calculation results are provided in tables 5 and 6 and figures 11-12. 
Table 5. Results of calculation of the oil-polluted soil and oil sludge activation energy during thermal treatment using solar energy

\begin{tabular}{|c|c|c|c|c|c|c|c|c|c|c|c|c|c|c|}
\hline \multicolumn{3}{|c|}{$303.5 \mathrm{~K}$} & \multicolumn{3}{|c|}{$309.5 \mathrm{~K}$} & \multicolumn{3}{|c|}{$315 \mathrm{~K}$} & \multicolumn{3}{|c|}{$328 \mathrm{~K}$} & \multicolumn{3}{|c|}{$336 \mathrm{~K}$} \\
\hline \multicolumn{15}{|c|}{ oil-polluted soil } \\
\hline$\alpha$ & $\mathrm{K}$ & $\mathrm{R}^{2}$ & $\alpha$ & K & $\mathrm{R}^{2}$ & $\alpha$ & $\mathrm{K}$ & $\mathrm{R}^{2}$ & $\alpha$ & $\mathrm{K}$ & $\mathrm{R}^{2}$ & $\alpha$ & $\mathrm{K}$ & $\mathrm{R}^{2}$ \\
\hline 0.11 & 0.000013 & 0.9892 & 0.19 & 0.000027 & 0.9892 & 0.44 & 0.000135 & 0.9892 & 0.59 & 0.000225 & 0.9892 & 0.72 & 0.000340 & 0.9892 \\
\hline$\alpha$ & $\mathrm{K}$ & $\mathrm{R}^{2}$ & $\alpha$ & $\mathrm{K}$ & $\mathrm{R}^{2}$ & $\alpha$ & $\begin{array}{c}\text { oil sludge } \\
\mathrm{K}\end{array}$ & $\mathrm{R}^{2}$ & $\alpha$ & $\mathrm{K}$ & $\mathrm{R}^{2}$ & $\alpha$ & $\mathrm{K}$ & $\mathrm{R}^{2}$ \\
\hline 0.21 & 0.000053 & 0.9696 & 0.29 & 0.000067 & 0.9696 & 0.62 & 0.000326 & 0.9696 & 0.79 & 0.000560 & 0.9696 & 0.88 & 0.000723 & 0.9696 \\
\hline
\end{tabular}

Table 6. Oil-polluted soil and oil sludge activation energy during treatment using solar energy

\begin{tabular}{|c|c|c|c|c|c|c|c|c|}
\hline \multirow[t]{2}{*}{$\mathrm{T}, \mathrm{K}$} & \multicolumn{2}{|c|}{$\mathrm{K}$} & \multicolumn{2}{|c|}{$\lg K$} & \multicolumn{2}{|c|}{$\mathrm{E}, \mathrm{kJ} / \mathrm{mol}$} & \multicolumn{2}{|c|}{$\mathrm{E}, \mathrm{kcal} / \mathrm{mol}$} \\
\hline & oil-poll. soil & oil sludge & oil-poll. soil & oil sludge & oil-poll. soil & oil sludge & oil-poll. soil & oil sludge \\
\hline 303.5 & 0.000013 & 0.000053 & -4.89 & -4.28 & & & & \\
\hline 309.5 & 0.000027 & 0.000067 & -4.57 & -4.17 & 2.17 & 695.67 & 0.518 & 166.16 \\
\hline 315 & 0.000135 & 0.000326 & -3.87 & -3.49 & 10.29 & 10.11 & 2.457 & 2.41 \\
\hline 328 & 0.000225 & 0.000560 & -3.65 & -3.25 & 4.72 & 5.00 & 1.127 & 1.19 \\
\hline 336 & 0.000340 & 0.000723 & -3.47 & -3.14 & 5.72 & 3.54 & 1.366 & 0.85 \\
\hline
\end{tabular}




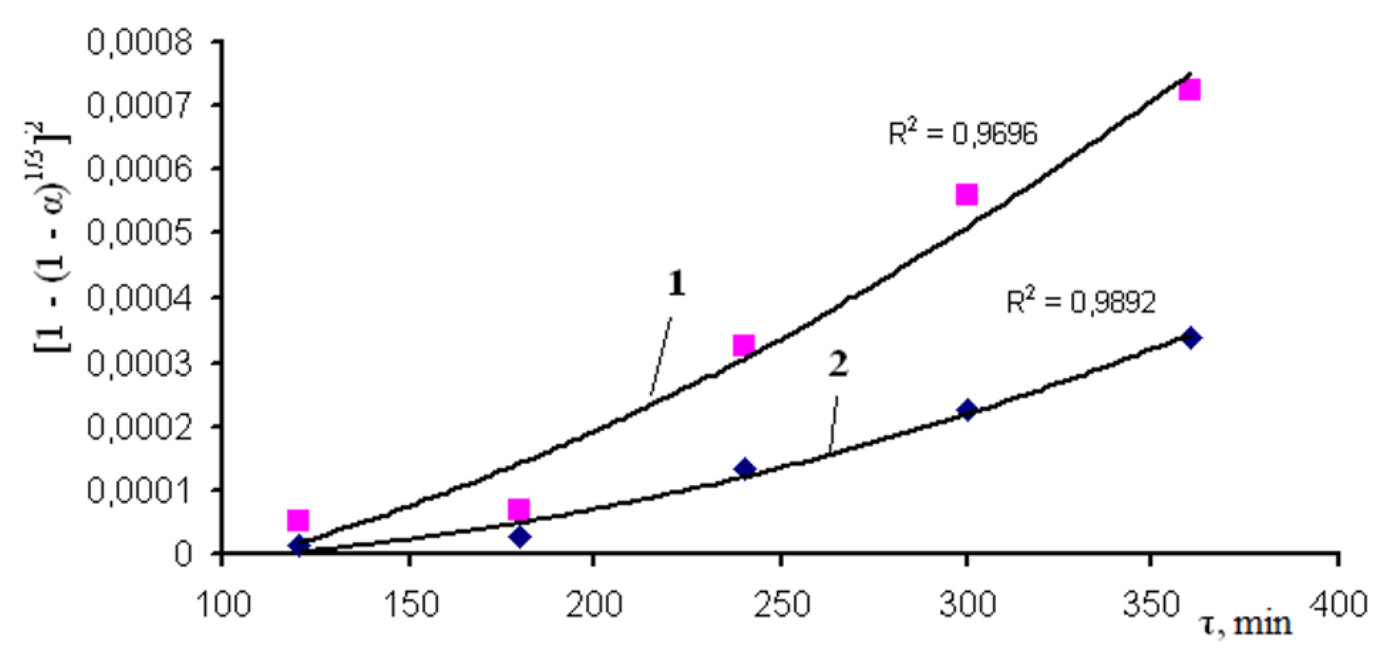

Figure 11. Dependence $\left(\left[1-(1-\alpha)^{1 / 3}\right]^{2}\right)=f(\tau)$

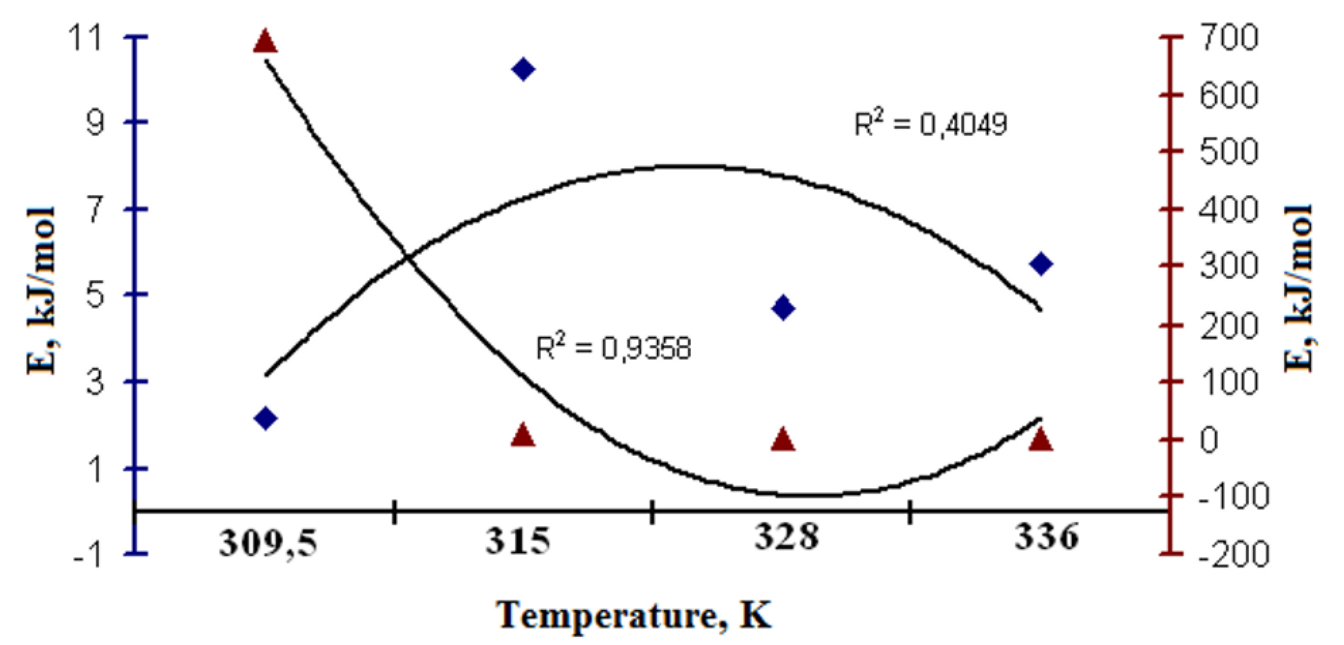

Figure 12. Oil-polluted soil and oil sludge activation energy during thermal treatment using solar energy

It is seen from the table that activation of oil sludge during thermal treatment requires $695.67 \mathrm{~kJ} / \mathrm{mol}$ of energy, which is 300 times higher than oil-polluted soil activation energy $(2.17 \mathrm{~kJ} / \mathrm{mol})$. However, in both cases, activation energy decreases with temperature increase. This is explained by the fact that temperature increase results in breaking of intermolecular bonds between asphaltene-tarry-paraffin substances in oil-containing wastes.

The result of the differential thermal analysis is given in figure 13. The DTA curve of oil-containing wastes heating before processing shows an intense extended exothermic effect with maxima in the temperature range of 200 to $680^{\circ} \mathrm{C}$ accompanied by weight loss of $12.7 \%$. Weight loss is indicative of burning-out of oil components present: hydrocarbons. Exo-effect at $(+) 260^{\circ} \mathrm{C}$ is caused by thermal decomposition of methane hydrocarbons. Exo-effect at $(+) 320^{\circ} \mathrm{C}$ implies paraffin fraction decomposition. Exo-effects at $(+) 410^{\circ} \mathrm{C}$ and $(+) 480^{\circ} \mathrm{C}$ imply decomposition of naphthenes. Exo-effect at $(-) 570^{\circ} \mathrm{C}$ is caused by crystallization of high-molecular hydrocarbons of paraffinic oil (mineral wax). 


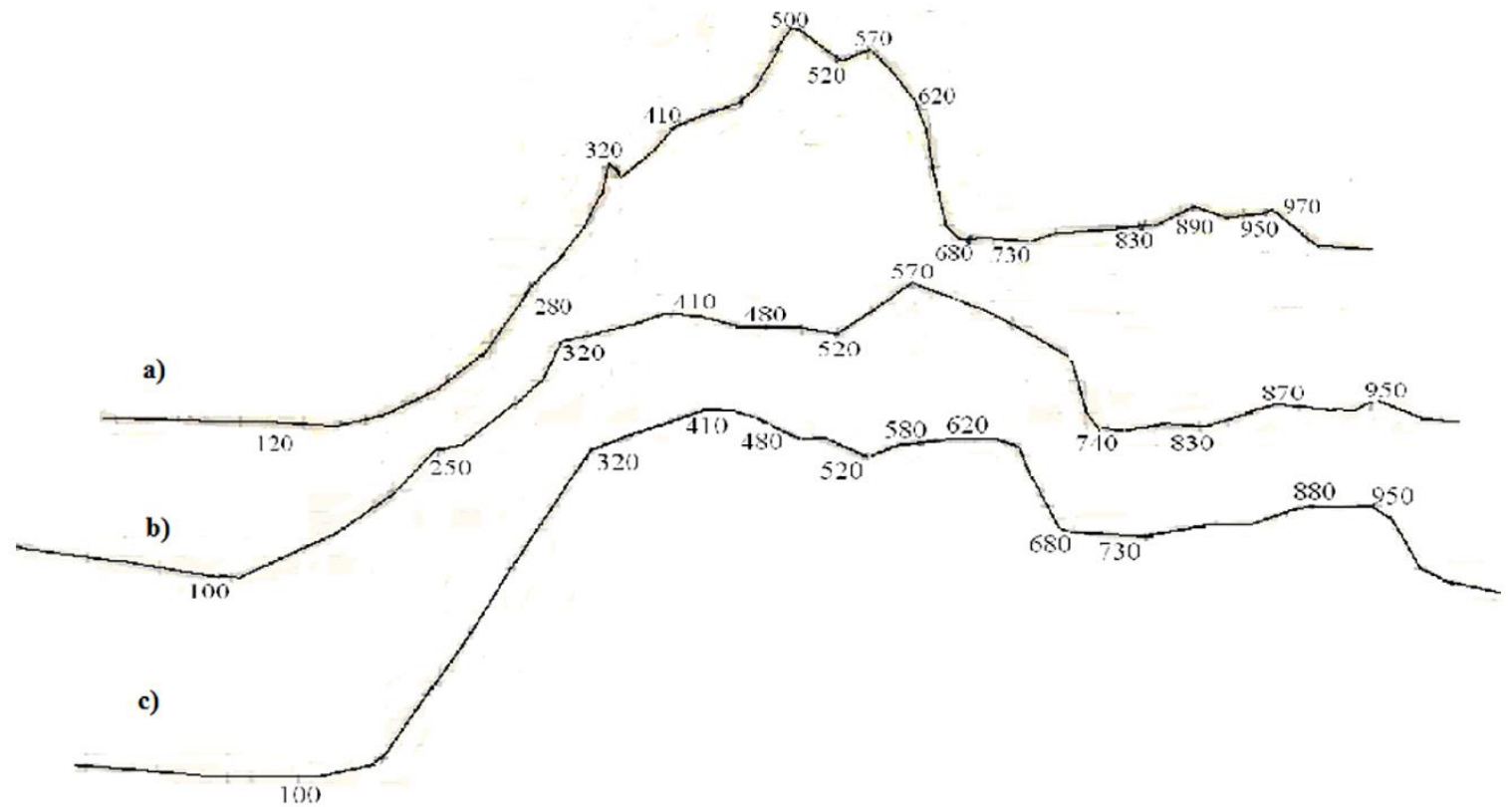

Figure 13. Thermograms of oil-containing wastes before treatment (a), after electrical thermal treatment (b) and after heating using solar energy (c)

The thermogram underwent changes after solar treatment of oil-containing wastes. Exo-effects with maxima of (+)480 and $(+) 570^{\circ} \mathrm{C}$ became less intense, which is indicative of decomposition of hightemperature fraction hydrocarbons with weight loss of $4.6 \%$.Endo-effect at $(-) 100^{\circ} \mathrm{C}$ is caused by adsorbed water decomposition.

Table 7. Material balance before thermal treatment

\begin{tabular}{lccccc}
\hline \multicolumn{1}{c}{ Product } & $\%$ & $\mathrm{~kg} / \mathrm{h}$ & $\mathrm{t} / \mathrm{hour}$ & $\mathrm{t} /$ day & $\mathrm{t}$ /year \\
\hline Oil sludge, including: & 100.00 & 50.0 & 0.05 & 0.25 & 325 \\
Solids & 8.0 & 4.0 & 0.004 & 0.02 & 26 \\
Oil products & 76.8 & 38.4 & 0.0384 & 0.192 & 249.6 \\
Water & 15.2 & 7.6 & 0.0076 & 0.038 & 49.4 \\
\hline Total & & 50.0 & 0.05 & 0.25 & 325 \\
\hline
\end{tabular}

Benchmarking of treatment methods (using solar and electric energy) yields the following conclusions:

1) Oil-containing wastes thermal treatment using solar and electric energy reduces the intensity of exo-effects:(+) $410^{\circ} \mathrm{C},(+) 480^{\circ} \mathrm{C}$ and $(+) 570^{\circ} \mathrm{C},(+) 620^{\circ} \mathrm{C}$ relating to the effects of high-molecular paraffin oil hydrocarbons result in decomposition of hydrocarbons.

2) Thermal treatment using solar energy has more effect on high-temperature hydrocarbon component of oil residue. Exo-effect $(+) 570^{\circ} \mathrm{C}$ below $(+) 480^{\circ} \mathrm{C}$.

3) Thermal treatment using electric energy, on the contrary, affects low-temperature hydrocarbon component of oil residue. Exo-effect $(+) 480^{\circ} \mathrm{C}<(+) 570^{\circ} \mathrm{C}$.

Fractional analysis of oil-polluted soils and oil sludge and their solid residue after treatment using solar energy in the designed device was conducted to study the efficiency of heat effect of solar energy on hydrocarbon properties.

After oil sludge thermal treatment using the plant, 3 end products are obtained:

- oil sludge derivative (organic fraction);

- water containing oil products; 
- sludge (cake) containing oil products

Table 8. Material balance after thermal treatment

\begin{tabular}{lccccc}
\hline \multicolumn{1}{c}{ Product } & $\%$ & $\mathrm{~kg} / \mathrm{h}$ & $\mathrm{t} / \mathrm{hour}$ & $\mathrm{t} / \mathrm{day}$ & $\mathrm{t} / \mathrm{year}$ \\
\hline Oil sludge, including: & 100 & 49.08 & 0.04908 & 0.2454 & 319.02 \\
Solids & 83.21 & 40.84 & 0.04084 & 0.204 & 265.2 \\
Oil products & 8.79 & 4.31 & 0.00431 & 0.022 & 28.6 \\
Water & 8.0 & 3.93 & 0.00393 & 0.0196 & 25.48 \\
\hline Total & & 49.08 & 0.04908 & 0.2454 & 319.02 \\
\hline
\end{tabular}

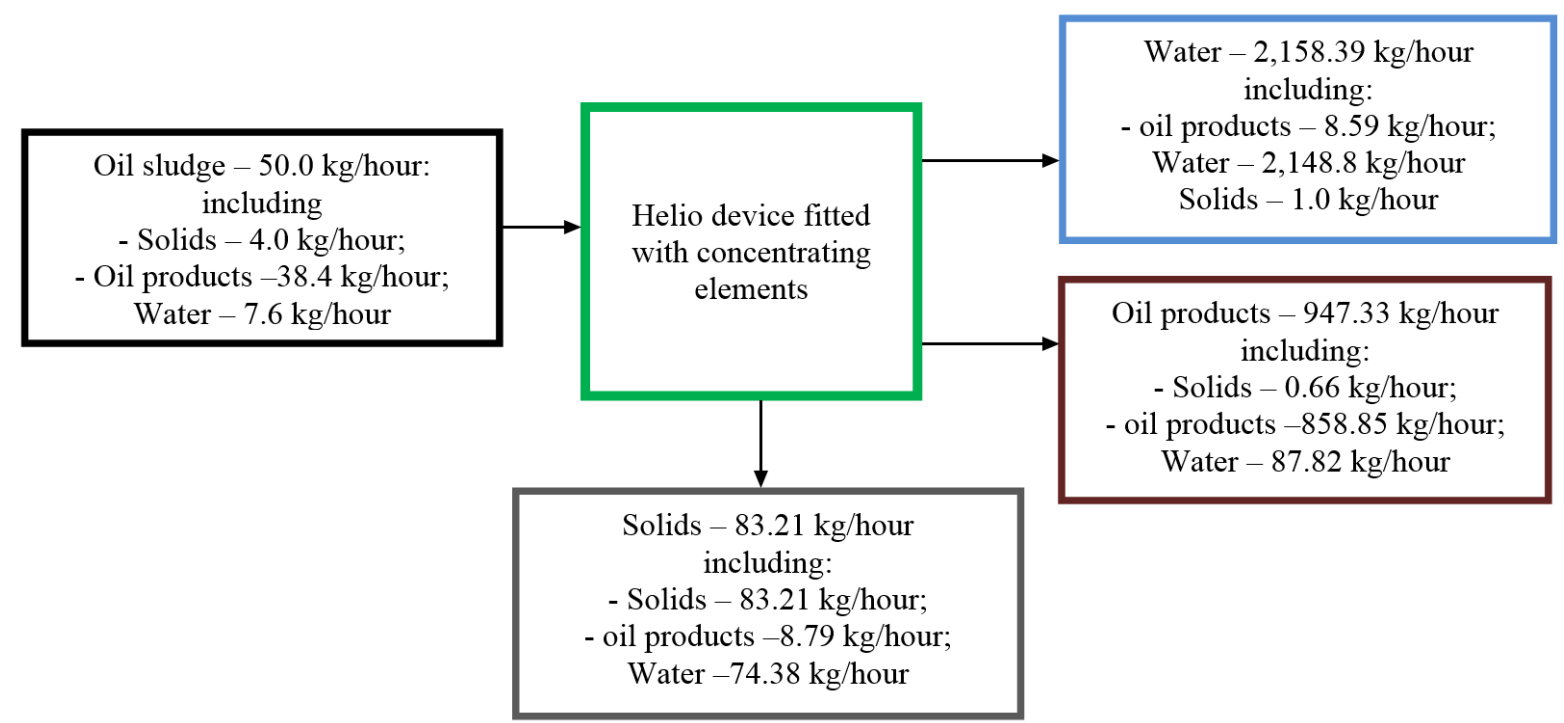

Figure 14. Diagram of oil sludge passage through the helio device

Thus, after oil-containing wastes purification using solar energy, the particulate load in soil does not exceed 8.65-8.79\%.After treatment, the absolute molecular weight of hydrocarbons approaches that of bitumen and carbon/hydrogen ratio changes as follows: bitumens (6.29-10.7) > oil-polluted soils or oil sludge (8.56-8.79).The benefits of this oil-containing wastes purification method in terms of oil and mineral fraction separation is simple design of the device, its high performance and relatively low price.

The above estimates and experimental data are provided in tabular form. Table 9 includes data of the solar radiation coming to the horizontal face by hours, estimated oil-containing wastes activation energy with various thermal treatment conditions and helio device performance. 
Table 9. Helio device performance with thermal treatment of oil-polluted soil and oil sludge

\begin{tabular}{|c|c|c|c|c|c|c|}
\hline \multirow{3}{*}{ Device } & \multicolumn{2}{|c|}{$\begin{array}{l}\text { Total solar radiation } \\
\text { coming to horizontal } \\
\text { face }\end{array}$} & \multicolumn{3}{|c|}{ Oil-containing wastes activation energy } & \multirow[t]{2}{*}{ Performance } \\
\hline & \multirow[b]{2}{*}{ Time, $\mathrm{h}$} & \multirow[b]{2}{*}{$\mathrm{S}, \mathrm{kJ} \cdot \mathrm{h} / \mathrm{m}^{2}$} & \multirow[b]{2}{*}{$\begin{array}{c}\text { Temperature, } \\
\text { K }\end{array}$} & \multicolumn{2}{|c|}{$\mathrm{E}, \mathrm{kJ} / \mathrm{mol}$} & \\
\hline & & & & $\begin{array}{l}\text { oil- } \\
\text { polluted } \\
\text { soil }\end{array}$ & $\begin{array}{l}\text { oil } \\
\text { sludge }\end{array}$ & $\eta$ \\
\hline \multirow{4}{*}{ Helio device } & 9.00 & $1,091.1$ & 309.5 & фев.17 & 695.67 & 0.27 \\
\hline & 10.00 & $1,143.5$ & 315 & окт.29 & 10.ноя & 0.30 \\
\hline & 11.00 & $1,172.4$ & 328 & апр.72 & 5.00 & 0.35 \\
\hline & 12.00 & $1,181.6$ & 336 & май.72 & мар.54 & 0.40 \\
\hline
\end{tabular}

\section{CONCLUSIONS}

Thus, after oil-containing wastes purification using solar energy, the particulate load in soil does not exceed $6.65-6.79 \%$. After treatment, the absolute molecular weight of hydrocarbons approaches that of bitumen. The raw materials disposed of using the helio device - treated soil - may find application in road construction. Thus, a sought-after "waste - initial stock - product" technology cycle may be created.

According to the developed technology, pre-neutralized oil waste may be used in the production of building materials - bricks, claydite, small building products, etc. Construction of cheap dirt roads reinforced with cement, lime, and other binding agents, the so-called "economy class" roads, may also be considered. These days, a method of soil reinforcement using processed oil wastes has gained the widest recognition among oil industry waste disposal methods for economic reasons. The practice of waste reutilization instead of storage or disposal allows to save place for storage, minimize the volume of waste, and reduce the environmental load due to the absence of material transportation and on-site waste use. In terms of use of the product obtained, such methods may be targeted at production of building, reclamation, and recultivating materials. Solar energy may be used as a source of energy required for disposal.

The helio device designed offers the following benefits:

- eco-friendly generation of heat energy;

- full absence of greenhouse gas emissions;

- utilization flexibility, simple and lightweight design, mobility for operation, modular ramp-up principle and high reliability;

- crude oil recovery from oil sludge back into circulation;

- minimum amount of oil impurities in the solid residue, which enables the use of the solid phase to obtain modern composite building material;

- oil content of 1.5-2.5\% in the water phase, which enables photochemical purification using ozone.

Helio device operation meets requirements of international environmental standard ISO 14000 as the helio device that separates waste into useful fractions has no environmental release.

The oil-containing wastes purification method developed solves an important environmental issue of oilcontaining wastes disposal, promotes recovery and prevents degradation of natural complexes, and reduces soil and water pollution. Thus, this technology of oil-containing wastes disposal will significantly mitigate the adverse environmental impact of pollutants.

Setting of new tasks and determination of new approaches to the arrangement of oil-containing wastes complex treatment are intended to change priorities in ongoing and scheduled operations for the purposes 
of environmental protection. The oil-containing wastes purification method under study is an important element of the overall process of environmental safety assurance.

\section{AUTHOR CONTRIBUTIONS}

All authors contributed equally.

\section{ACKNOWLEDGEMENT}

This study was conducted in the framework as part of a grant financing project of the Kazakhstan Ministry of Education and Science in: "Extraction of oil in cleaning oil-containing wastes in helio devices equipped with concentrating elements."

\section{AUTHOR DISCLOSURE STATEMENT}

Conflicts of Interest: The author declares that here are not conflicts of interest.

\section{REFERENCES}

Abdibattayeva, M, Beketova, A., \& Rysmagambetova, A. (2013). Development of Methods for Extraction of Oil in Cleaning Oil Waste Using Devices Equipped with Solar Concentrating Elements. Geoconference on Energy and Clean Technologies Series: International Multidisciplinary Scientific GeoConferenceSGEM (pp. 85-90). Albena, Bulgaria.

Abdibattayeva, M. M. (2015). Method of cleaning oil-contaminated soils and sludge. Russian Federation Patent No. 30222. Published 17.08.2015, bulletin No. 8

Abdibattayeva, M., Berdikulova, F., Beketova, A. (2014). Profound Thermal Treatment of Oil Waste in Heliodevices Equipped with Concentrated Elements. Geoconference on Energy and Clean Technologies, Vol 1 (Sgem 2014) Series: International Multidisciplinary Scientific GeoConference-SGEM (pp. 425431). Albena, Bulgaria

Abdibattayeva, M., Bisenov, K., and Rysmagambetova, A. (2016). Integrated Oil Waste Processing with Using Solar Energy. Collected materials of the conference. Energy and Clean Technologies Conference Proceedings Sgem 2016 vol. I. Series: International Multidisciplinary Scientific GeoConference-SGEM (pp. 443-450). Albena, Bulgaria.

Abdibattayeva, M., Umbetbekov, A., \& Kalimbetov, G. (2015). Extraction of Oil in Cleaning Oilcontaining wastes in Helio Devices Equipped with Concentrating Elements. In Proceedings of the 2015 International Conference on Materials, Environmental and Biological Engineering (MEBE) Series: AERAdvances in Engineering Research vol. 10 (pp. 258-261). China: Guilin.

Abdibattayeva, M. M., Akhmedzhanov, T. K., and Zhubandykova Zh. U. (2007). Disposal of oilcontaining wastes at Kumkol site using solar energy. In International Research and Practical Conference News in health and safety vol. 2 (pp. 129-135). Almaty: KazNTU.

Abdibattayeva, M. M., Berdikulova, F., Beketova, A., Umbetbekov, A., \& Kalimbetov, G. (2013). Development of methods for extracting oil in the purification of waste oil with the use of solar energy. World Applied Sciences Journal, 10, 1331-1335. 
Abdrakhmanov, Z., Zakirov, B., \& Andreyev, V. (1997). New methods of cleaning oil from polluted soil. Oil and Gas of Kazakhstan, 3, 36-37.

Abzhapparov, A., Nurmagambetov, Kh. N., \& Eremin, N. I. (1978). Sintering kinetics of clay AP-3 and red mud. Metallurgy and concentration, 13, 10-16.

Bare, P. (1976). Kinetics of heterogeneous processes. Moscow: Mir.

Emanuel, N. M., \& Knorre, D. (1974). Course of chemical kinetics. Moscow: High school.

Estrada-Arriaga, E. B., Zepeda-Aviles, J. A., Garcia-Sanchez, L. (2016). Post-treatment of real oil refinery effluent with high concentrations of phenols using photo-ferrioxalate and Fenton's reactions with membrane process step. Chemical Engineering Journal, 285, 508-516. doi: 10.1016/j.cej.2015.10.030.

Guangji, H., Jianbing, L., \& Guangming, Z. (2013). Recent development in the treatment of oily sludge from petroleum industry. A review. Journal of Hazardous Materials, 261, 470-490.

Kurbskiy, G. P. (1987). Geochemistry of Tatarstan oil. Moscow: Nauka.

Obrevka, L. A., Frolova, V. A, \& Darisheva, A. M. (2002). Environmental problems and oil industry waste disposal. Almaty: KazgosINTI.

Ongarbaev, E. K., \& Mansurov, Z. A. (2003). Oil waste and relevant disposal methods. Almaty: Kazakh University.

Ospanov, Kh. K. (2006). Kinetics of homogeneous and heterogeneous chemical processes. Almaty: Kazakh University.

Pak, V. (1997). Modular oil and sludge miniplants. Oil and Gas of Kazakhstan, 3, 33-35.

Pavlyuchenko, M.M. (Ed.) (1961). Heterogeneous chemical reactions. Minsk: High special education BSSR Publishing.

Robinson, W. T., Cundiff, R. H., \& Markunas, P. C. (1961). Rapid Determination of Organic Hydroxyl Groups with 3,5 - Dinitrobenzoyl Chloride. Analytical Chemistry, 33(8), 1030-1034. doi: $10.1021 / \mathrm{ac} 60176 \mathrm{a} 050$.

Rozovskiy, A. Ya. (1989). Heterogeneous chemical reactions. Moscow: Nauka.

Use and disposal of oil hills (2018). Scriru.comhttp://www.scriru.com/7/19/93869698817.php. Access: 18 Jan. 2018.

Singh, P., Ojha, A., Borthakur, A., Singh, R., Lahiry, D., Tiwary, D., \& Mishra, P. K. (2016). Emerging trends in photodegradation of petrochemical wastes: a review. Environmental Science and Pollution Research, 23(22), 22340-22364.

Smykov, V.V., Smykov, Yu. V., \& Torikov, A. I. (2005). About the problem of oil-containing wastes disposal. Neftyanoye khozyaystvo (Oil economy), 3, 30-33.

Stilianos, G. R., \& Andrew, S. C. (1997). Simplified Hydrocarbon Compound Type Analysis Using a Dynamic Batch Inlet System Coupled to a Mass Spectrometer. Research Department, Products and 
Chemicals Division, Imperial Oil, Sarnia, Ontario, Canada N7T 7M1. Energy Fuels, 11(4), 879-886. doi: 10.1021/ef960221j.

Stilianos, G. R., \& Fitzgerald, P. W. (2000). Gas chromatographic simulated distillation-mass spectrometry for the determination of the boiling point distributions of crude oils. Journal Analytical chemistry, 72(7), 1400-1409.

Swanberg, C. (1993). MX-2500 Thermal processor for the treatment of petroleum refining wastes and contaminated soils. Environmental Progress, 12(2), 160-162.

Taciuk, W., Caple, R., Goodwin, S., and Taciuk, G. (1993). Dry thermal processor. USA Patent No. 5217578, published 08.06.93.

Tretyakov, Yu. D. (1978). Solid state reactions. Moscow: Khimiya.

\section{SEMBLANCE OF THE AUTHORS}

Maral Abdibattayeva: Doctor of Technical Sciences, Associate Professor, Acting Professor of the UNESCO Chair in Sustainable Development of Al-Farabi Kazakh National University.

Kylyshbay Bissenov: Doctor of Technical Sciences, Professor, Rector of the Kyzylorda State University named after Korkyt ata.

Zheniskul Zhubandykova: Candidate of Technical Sciences, Associate Professor of the Department of Oil and Gas Business Aktobe Regional State University.

Raigul Orynbassar: Candidate of Chemical Sciences, Head of Department of Oil and Gas Business Aktobe Regional State University.

Lyazzat Tastanova: Associate Professor of the Department of Chemistry and Chemical Technology Aktobe Regional State University. 